Article

\title{
Evaluating the Potential for Combustion of Biofuels in Grate Furnaces
}

\author{
Małgorzata Wzorek \\ Department of Process Engineering, Faculty of Mechanical Engineering, Opole University of Technology, \\ ul. Prószkowska 76, 45-758 Opole, Poland; m.wzorek@po.edu.pl; Tel.: +48-77-449-8779
}

Received: 11 March 2020; Accepted: 10 April 2020; Published: 15 April 2020

\begin{abstract}
The paper assesses the impact of combustion of biofuels produced based on municipal sewage sludge in stoker-fired boilers on the amount of pollutant emissions and examines the tendency of ash deposition of biofuels formed during the combustion process. The combustion tests were performed in a laboratory system enabling simulation of a combustion process present in stoker-fired boilers. The study was conducted for three types of biofuels; i.e., fuel from sewage sludge and coal slime (PBS fuel), sewage sludge and meat and bone meal (PBM fuel) and fuel based on sewage sludge and sawdust (PBT) with particle size of $35 \mathrm{~mm}$ and $15 \mathrm{~mm}$. This paper describes and compares the combustion process of biofuels with different granulation and composition and presents the results of changes in emission values of $\mathrm{NO}_{\mathrm{x}}, \mathrm{SO}_{2}, \mathrm{CO}$, and $\mathrm{CO}_{2}$. The emission results were compared with the corresponding results obtained during combustion of hard coal. The results showed that biofuels with lower particle sizes were ignited faster and the shortest ignition time is achieved for fuel based on sewage sludge and coal slime-PBS fuel. Also, the highest $\mathrm{NO}$ and $\mathrm{SO}_{2}$ emissions were obtained for PBS fuel. During the combustion of fuel based on sewage sludge and meat and bone meal (PBM), on the other hand, the highest $\mathrm{CO}_{2}$ emissions were observed for both granulations. Biofuels from sludge show a combustion process that is different compared to the one for hard coal. The problems of ash fouling, slagging, and deposition during biofuels combustion were also identified. The tendency for ash slagging and fouling is observed, especially for fuel from sewage sludge and meat and bone meal (PBM) and fuel based on sewage sludge and sawdust (PBT) ashes which consist of meat and bone meal and sawdust which is typical for biomass combustion.
\end{abstract}

Keywords: sewage sludge; biofuels; combustion; grate furnace; emission; ash deposition

\section{Introduction}

Municipal sewage sludge is a product of the water-cleaning process in wastewater treatment plants. The amount of generated sewage sludge depends on many factors, mainly on the content of pollutants in the sludge and on the technology of its treatment. An amount of sewage sludge cannot be prevented and is reduced in line with the requirements regarding the quality of treated sewage.

The problem of sewage sludge disposal has two aspects: quantitative and qualitative aspect, which results from the specific properties of the waste and the legal aspect.

The problem with the disposal of municipal sewage sludge also results from the introduction of new, increasingly stringent legal regulations concerning sewage sludge management, limiting the use of the sludge for agricultural and natural purposes and prohibiting its storage [1,2].

In this situation, processes that are becoming increasingly important are thermal use processes which are among the most radical methods in terms the possibility of a significant reduction in the mass and volume of sewage sludge. They also allow use of the energy contained in the sludge and to reduce $\mathrm{CO}_{2}$ emissions in accordance with the principles of sustainable development. 
The parameter that is very important for the use of waste to generate energy is the stability of the properties which determines the efficiency of the combustion process, and in the case of sewage sludge it is difficult to talk about stability, since the properties of the sludge vary widely and are dependent on many factors.

Another problem in the thermal use of municipal sludge is its high water content. With a dry matter content of $20 \%-30 \%$, municipal sewage sludge can be incinerated only with the help of additional fuel, and only after partial drying up to $50 \%$ can they be burnt autothermally [3]. The total drying of sludge, up to about $10 \%$, allows their use in co-combustion with coal in industrial processes $[4,5]$. Another way to use sludge for energy purpose is to use it as an ingredient in the production of fuel with fixed composition and properties [6].

Research on the thermal degradation of sludge combustion and co-combustion with coal and other fuels are conducted both on a laboratory and industrial scale.

Thermogravimetric analysis (TGA) is a technique that is most widely and commonly used for this purpose. Many authors emphasize the specificity of behavior of sewage sludge in combustion process. For example, Lin et al. [7] showed that the co-combustion of sewage sludge and oil shale with a proportion of $10 \%$ of the sludge gave the best promoter effect. It was observed that the ignition temperature shifted to an earlier temperature when sewage sludge was added.

Chen et al. [8] had studied co-combustion characteristics of sewage sludge and coffee grounds mixtures (mixing ratios of 9:1, 8:2, 7:3 and 6:4) using thermogravimetric analysis coupled to artificial neural networks modeling. The results showed interactions between the components, and with the addition of coffee grounds ignition temperature, maximum mass loss rate, and the reactivity of sewage sludge increased while charring was reduced.

The authors also presented testes of co-combustion sewage sludge with straw [9], olive and animal waste [10], shiitake substrate [11], rice husk [12] and also with water hyacinth in $\mathrm{CO}_{2} / \mathrm{O}_{2}$ atmosphere [13]. All the above research was carried out for mixtures of fuels in the form of powder, for samples of $10 \mathrm{mg}$.

Investigations of co-combustion of sewage sludge in a pelletized form, on a small laboratory scale, were conducted, among others by Akdağ et al. [14], who studied co-combustion of sewage sludge with coal $(3 \%, 5 \%, 10 \%, 20 \%$ and $30 \%)$ in a laboratory batch reactor. Kijo-Kleczkowska et al. [15] tested the co-combustion of pelletized $(10 \mathrm{~mm})$ sewage sludge with coal and willow Salix viminalis. Junga et al. [16] studied the combustion of sewage sludge-based pellets and agriculture waste in $10 \mathrm{~kW}$ understocker boiler.

The literature also reports on the large-scale combustion and co-combustion of coal and sewage sludge in grate furnaces $[17,18]$. This process is mainly carried out in fluidized and pulverized-fuel boilers $[19,20]$.

The impact of co-combustion of sewage sludge on boiler efficiency, the amount of pollutant emissions and its impact on the environment is widely discussed in the literature.

The grate boiler furnaces are used for co-combustion of hard coal with biomass and waste fuels, including sewage sludge $[5,21,22]$. Werle [23] presented, among others, an analysis of the possibility of co-combustion of sewage sludge with coal (blends of $0 \%-20 \%$ ) in a WR-25 power station. It was found that an increase in the mass of the sewage sludge in the fuel blend causes a significant reduction in $\mathrm{CO}_{2}$ emissions to the atmosphere.

Nadziakiewicz et al. [18] investigated the changes in emissions of $\mathrm{CO}, \mathrm{NO}_{\mathrm{x}}$, and $\mathrm{SO}_{2}$ during co-combustion of dried sewage sludge with coal in the laboratory stoker-fired boiler. The tests show that the emissions of air pollutants increase with the increase in sludge ratio in the fuel mixture. Houshfar et al. [24], on the other hand, conducted an experimental investigation on the $\mathrm{NO}_{\mathrm{x}}$ formation and reduction, among others, for sewage sludge mixtures with straw and wood pellets.

The main issue in burning waste fuels and biomass in power boilers is a different, than that of coal, chemical, and mineral composition of ash. The presence of components with low melting point in the 
ash from those fuels poses the risk of slag formation and problem of powdered material (pollutants) sedimentation of heated surfaces of heat exchangers.

Ashes in the temperature range between softening and melting point tend to stick (adhere). The transformations of minerals contained in the fuel, taking place under the furnace chamber conditions, often also lead to the formation of compounds (or their combinations) characterized by particularly low melting points [25].

To assess the propensity of fuel to slag and contaminate the heating surface, several different value indicators based on ash oxide analysis [25-27] have been developed, which include:

- $\quad B / A$ ratio- - the ratio of the alkaline to acidic oxides in the ash base-to-acid ratio:

$$
B / A=\frac{\mathrm{Fe}_{2} \mathrm{O}_{3}+\mathrm{CaO}+\mathrm{MgO}+\mathrm{Na}_{2} \mathrm{O}+\mathrm{K}_{2} \mathrm{O}}{\mathrm{SiO}_{2}+\mathrm{Al}_{2} \mathrm{O}_{3}+\mathrm{TiO}_{2}}
$$

for biomass it also includes $\mathrm{P}_{2} \mathrm{O}_{5}$ content- $B / A_{+}$index

- $\quad$ Slagging index Rs

$$
R_{s}=\left(\frac{B}{A}\right) \cdot A^{d}
$$

where: $A^{d}$ is the percentage of ash in dry fuel.

- Fouling index $F_{u}$-index of the probability of heated surfaces fouling

$$
F_{u}=\left(\frac{B}{A}\right) \cdot\left(N a_{2} \mathrm{O}+K_{2} \mathrm{O}\right)
$$

- $\quad$ Slag viscosity index $S_{R}$

$$
S_{R}=\frac{\mathrm{SiO}_{2}}{\mathrm{SiO}_{2}+\mathrm{Fe}_{2} \mathrm{O}_{3}+\mathrm{CaO}+\mathrm{MgO}}
$$

- $\mathrm{Fe}_{2} \mathrm{O}_{3} / \mathrm{CaO}$ ratio informing about the emergence of slag-promoting eutectic.

Numerous studies have been. devoted to the mechanism of ash formation and the behavior of mineral matter in the processes of co-combustion of coal with other fuels with low caloric value, in particular biomass, among others with biomass [28-31] and sewage sludge $[25,32,33]$ in large and small scale.

Furthermore, an important issue, while using fuels from waste and biomass is also sufficient mixing of the fuel on the grate, which is expected to prevent from such detrimental effects as local material overheating, leading to slag formation, furnace chamber damage, and grate overburning.

An important parameter of the fuel combusted on a grate is its grain composition. Improper choice of the fuel grain size composition may lead to considerable loss of unburnt carbon in the slag and fly ash, since the content of combustibles in the slag may be even $25-30 \%$ of its weight, and in the fly ash $15-20 \%$ [34].

In stoker-fired boilers, fuels with grain sizes $0-25 \mathrm{~mm}$ are usually burnt, with less than $25 \%$ 0-2 mm fractions.

Most of the stoker-fired boilers in use are not equipped in any flue gas treatment systems, except for the simplest dedusting equipment. The need to upgrade the flue gas treatment system, in order to comply with the emission standards and to adjust the flue system to the requirements of waste co-combustion process (conditions related to the minimum flue gas presence and minimum temperature in the furnace chamber) is the main subject of numerous discussions.

The aim of the study is to evaluate the potential of the combustion of biofuels made of municipal sewage sludge and other materials in grate furnaces. Three types of biofuels were tested; i.e., fuel based on sewage sludge and coal slime (PBS), sewage sludge and meat and bone meal (PBM) and sewage sludge and sawdust (PBT) with particle size of $35 \mathrm{~mm}$ and $15 \mathrm{~mm}$. The impact of the fuel pellet size on the combustion process and on the emission of pollutants was taken into account. Additionally, 
the objective of this paper is the evaluation of ash deposits formed during the tests to establish the deposition behavior of biofuel pellets.

\section{Materials and Methods}

\subsection{Materials}

The combustion tests were performed on fuels made of municipal sewage sludge and other materials such as coal sludge, meat and bone meal, and sawdust. The technology of the sewage sludge fuel production consists of the initial mixing of the components and the subsequent proportions and simultaneous granulation and drying in the purpose made drum granulator. The drum is equipped with a feeder system ensuring the granulate diameter in the range from 15 to $35 \mathrm{~mm}[10,35,36]$. The combustion tests were performed on biofuels made of:

- $60 \mathrm{wt} . \%$ of sewage sludge, $34 \mathrm{wt} . \%$ coal sludge and $6 \mathrm{wt} . \%$ of quicklime-PBS fuel,

- $75 \mathrm{wt} . \%$ of sewage sludge, $24 \mathrm{wt} . \%$ of meat and bone meal, $1 \mathrm{wt} . \%$ of quicklime-PBM fuel,

- $80 \mathrm{wt} . \%$ of sewage sludge, $19 \mathrm{wt} . \%$ of sawdust and $1 \mathrm{wt} . \%$ of quicklime-PBT fuel.

The purpose of mixing sewage sludge with other components is, among others, to reduce its initial moisture of sewage sludge. The mixtures-following mixing and granulation-present a moisture content ranging from 40 to $60 \%$. They are subsequently dried to content of moisture about $10 \%$ in a solar drier using solar energy. The method has been patented [37] and recommended because of much lower production costs compared with conventional methods of high-temperature drying.

Energy properties of the fuels are listed in Table 1.

Table 1. Energy properties of fuels from sewage sludge.

\begin{tabular}{ccccc}
\hline Parameter & Unit & PBS & PBM & PBT \\
\hline Lower Heating Value, LHV & MJ/kg & 19.30 & 14.59 & 13.23 \\
Moisture & $\%$ & 8.58 & 8.67 & 10.37 \\
Voltaire matter & \% d.m. & 34.44 & 55.29 & 59.87 \\
Ash & \% d.m. & 27.26 & 33.72 & 20.36 \\
\hline \multicolumn{5}{c}{} \\
Carbon & Elementary analysis \\
Hydrogen & & 50.28 & 36.64 & 31.42 \\
Oxygen & & 15.01 & 4.12 & 4.43 \\
Nitrogen & \% d.m. & 1.72 & 6.67 & 40.50 \\
Sulphur & & 1.16 & 0.68 & 0.61 \\
Chlorine & & 0.06 & 0.02 & 0.03 \\
\hline & d.m.-dry mass. &
\end{tabular}

Fuels with pellet sizes $35 \mathrm{~mm}$ and $15 \mathrm{~mm}$ were tested in order to evaluate the effect of grain size on the combustion process and emission of pollutants.

The argument confirming the implementation of the research is the fact that most of the standards and techniques used to determine fuel parameters are based on the use of fuels in a powder form. Conducting research on combustion of sludge fuels under primary grain size analysis and under conditions simulating the real facility in which these fuels can be used, may give a picture of the combustion process that is more accurately resembling the process in industrial installations.

\subsection{Combustion Testes}

The combustion tests were performed on a laboratory scale at the Silesian University of Technology, Department of Technologies and Installations for Waste Management. This system is used for testing combustion of various types of waste and waste fuels. 
The main component of the test stand is a boiler with special construction that enables simulation combustion processes present in water boilers with a stationary and mechanical grate. The boiler comprises two main parts: the bottom one with adjustable heating temperature (up to $120{ }^{\circ} \mathrm{C}$ ), and the top one with water jacket.

The test stand is schematically shown in Figure 1. In the tests, the type of fuel fired was adopted as the input value (variable), and based on a series of initial tests and literature data, the following constant values were adopted as the system operating parameters:

- thickness of the bed of fuel being burnt -ca. $75 \mathrm{~mm}$ (each time $2.5 \mathrm{~kg}$ sample was burnt);

- process duration $-3600 \mathrm{~s}$ from starting air feeding to the combustion chamber;

- $\quad$ air excess ratio in the furnace chamber $\lambda=1.8$;

- $\quad$ secondary air stream $-5 \mathrm{Nm}^{3} / \mathrm{h}$;

- initial temperature in the combustion chamber $-900{ }^{\circ} \mathrm{C} \pm 10 \mathrm{~K}$;

- minimum temperature during the combustion process $-800^{\circ} \mathrm{C}$.

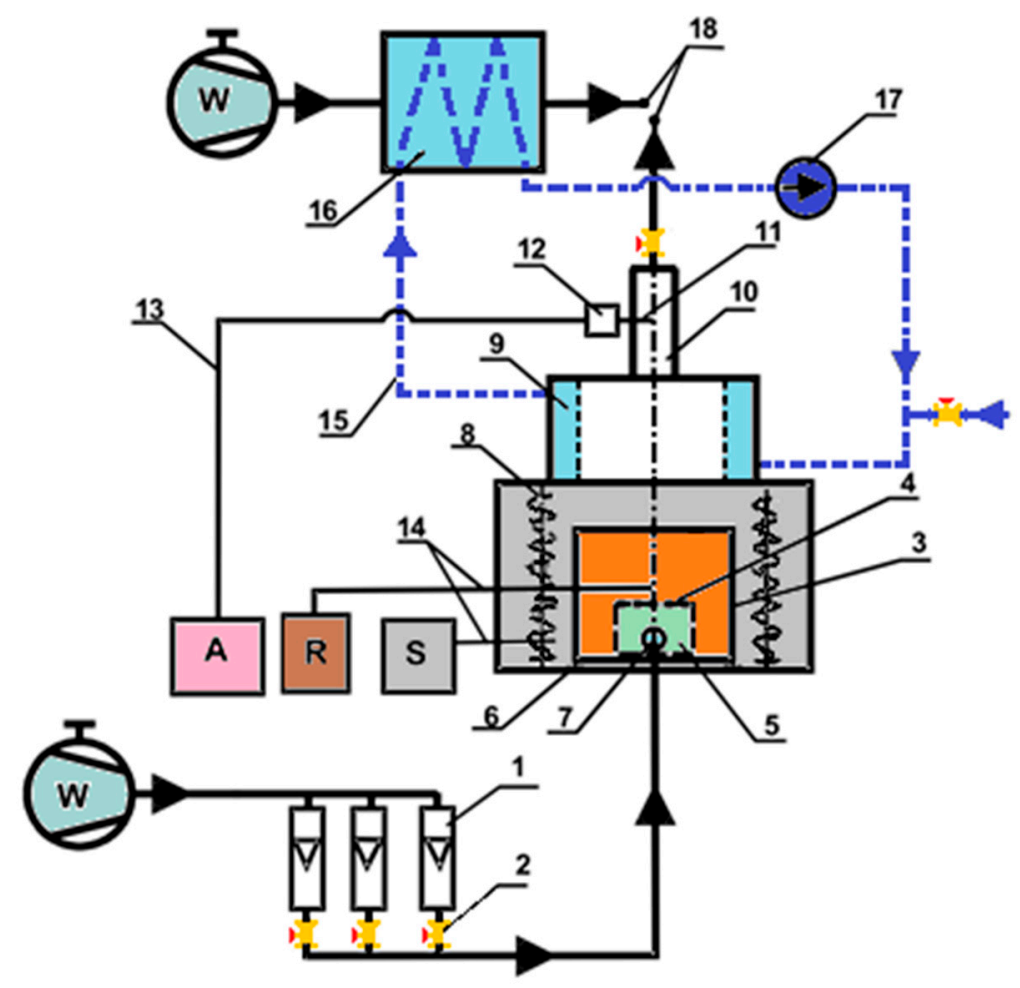

Figure 1. Test stand diagram [38]: A-flue gas analyzer, S-furnace control system, R-recorder, W-ventilator, 1-rotameter, 2-valve, 3-reciprocal bed with a grate, 4-grate, 5-plenum system (ash pit), 6-rail, 7-air nozzle, 8-heating element (electrical), 9-water jacket, 10-stack, 11-measuring probe, 12-probe head, 13-heated hose, 14-thermo elements with compensating cables, 15-cooling water circuit, 16-water/air heat exchanger (cooler), 17-circulation pump, 18 - ambience.

The measurement method which was used based on placing samples in a chamber preheated to the required temperature of $900^{\circ} \mathrm{C}$. To expedite loading the fuel sample into the oven chamber and arranging it on the grate as needed, the grate was mounted on a movable bed which, having been heated to the required temperature, was then slid inside.

While the sample was being heated, but prior to the ignition point, secondary air was supplied to the combustion chamber at a constant rate of $5 \mathrm{~m}^{3}$.

The secondary air was supplied after one of the below listed parameters had reached the limit value: 
- $\mathrm{CO}$ concentration at the measuring point $-6000 \mathrm{ppm}$,

- $\mathrm{CO}_{2}$ concentration higher than $1 \%$.

Two different streams of air fed to the process took place during measurements (one for the ignition phase and another one for the combustion phase).

Table 2 also shows the times the primary air was first fed to the combustion chamber (the starting point of the combustion process after the sample had been placed in the combustion chamber).

Table 2. Starting time of the combustion process.

\begin{tabular}{ccccccc}
\hline \multirow{2}{*}{ Kind of Biofuels } & \multicolumn{2}{c}{ PBS } & \multicolumn{2}{c}{ PBM } & \multicolumn{2}{c}{ PBT } \\
\cline { 2 - 7 } & $\mathbf{3 5} \mathbf{~ m m}$ & $\mathbf{1 5} \mathbf{~ m m}$ & $\mathbf{3 5} \mathbf{~ m m}$ & $\mathbf{1 5} \mathbf{~ m m}$ & $\mathbf{3 5} \mathbf{~ m m}$ & $\mathbf{1 5} \mathbf{~ m m}$ \\
\hline Starting Time of the Combustion Process, $\mathrm{s}$ & 600 & 420 & 1800 & 1500 & 330 & 480 \\
\hline
\end{tabular}

During the tests, MGA 5 MRU flue gas analyzer was used, with a heated probe and internal flue gas conditioner. The analyzer allows measuring of flue gas composition with reference methods (measuring $\mathrm{CO}_{2}, \mathrm{CO}, \mathrm{NO}, \mathrm{NO}_{2}, \mathrm{SO}_{2}$-NDIR sensor; $\mathrm{O}_{2}$-electrochemical sensor). During the tests, the concentration of measured gases: $\mathrm{CO}_{2}(0 \%-21 \%), \mathrm{CO}(0 \%-5 \%), \mathrm{NO}(0-10000 \mathrm{ppm}), \mathrm{NO}_{2}(0-500 \mathrm{ppm})$, $\mathrm{SO}_{2}(0-10000 \mathrm{ppm})$ in the flue gas was continuously measured.

Since the systems with fixed grates operate mainly in quasi-steady state at the most, to determine fuel behavior on the grate, gaseous pollutants were measured from feeding the fuel to the combustion chamber to the process end. Presentation of results for the entire combustion time enables forecasting of system operation in steady conditions (average value) and is a source of knowledge allowing forecasting the degree of emission variations in unstable operating conditions.

\subsection{Anlayses of Ash and Slag}

The chemical composition of ashes was analyzed by using the ICP method, and the remaining component levels-using the PANalitical XRF method.

Ash behavior and deposition tendencies were predicted through the use of empirical indices according to equations 1 to 4 .

The residues after combustion process were analyzed for the presence of combustible matter in the slag and ash according to PN-90-G-04512.

Additionally, slag and ash were tested for leaching hazardous compounds. For that reason, water extracts were created according to PN-EN 12457-4:2006, and in the water eluates, among others, chlorides (according to PN-ISO 9297), sulfides (PN-74/C-04566) and the heavy metal ions were determined with Perkin-Elmer Plasma 400 ICP Emission Spectrometer.

\section{Results and Discussion}

\subsection{Combustion Process of Fuels from Sewage Sludge}

The combustion process of fuels from sewage sludge, along with the variations of $\mathrm{CO}_{2}, \mathrm{CO}, \mathrm{NO}$, $\mathrm{SO}_{2}$ emissions, is graphically shown in Figures 2-5.

As the ' 0 ' moment, the start of air feeding to the combustion process was assumed. The earlier time is marked with negative values. Fuels were introduced into the combustion chamber in the time marked as $-1800 \mathrm{~s}$.

Emissions measured while burning fuels from sewage sludge were compared to the average values for hard coal combustion (particle diameter 15 to $30 \mathrm{~mm}$ ) [38]. Biofuels were feed to chamber at time marks such as (1800 s). Changes of $\mathrm{CO}_{2}$ emissions shown in Figure 2 best reflect the variations of combustion intensity. Analyzing the variations of $\mathrm{CO}_{2}$ emission while combustion of biofuels with the same composition, but different particle size, great similarity can be noted. The most intense burning process was observed between 250 and 1800 s; after that the $\mathrm{CO}_{2}$ decreased slowly. 


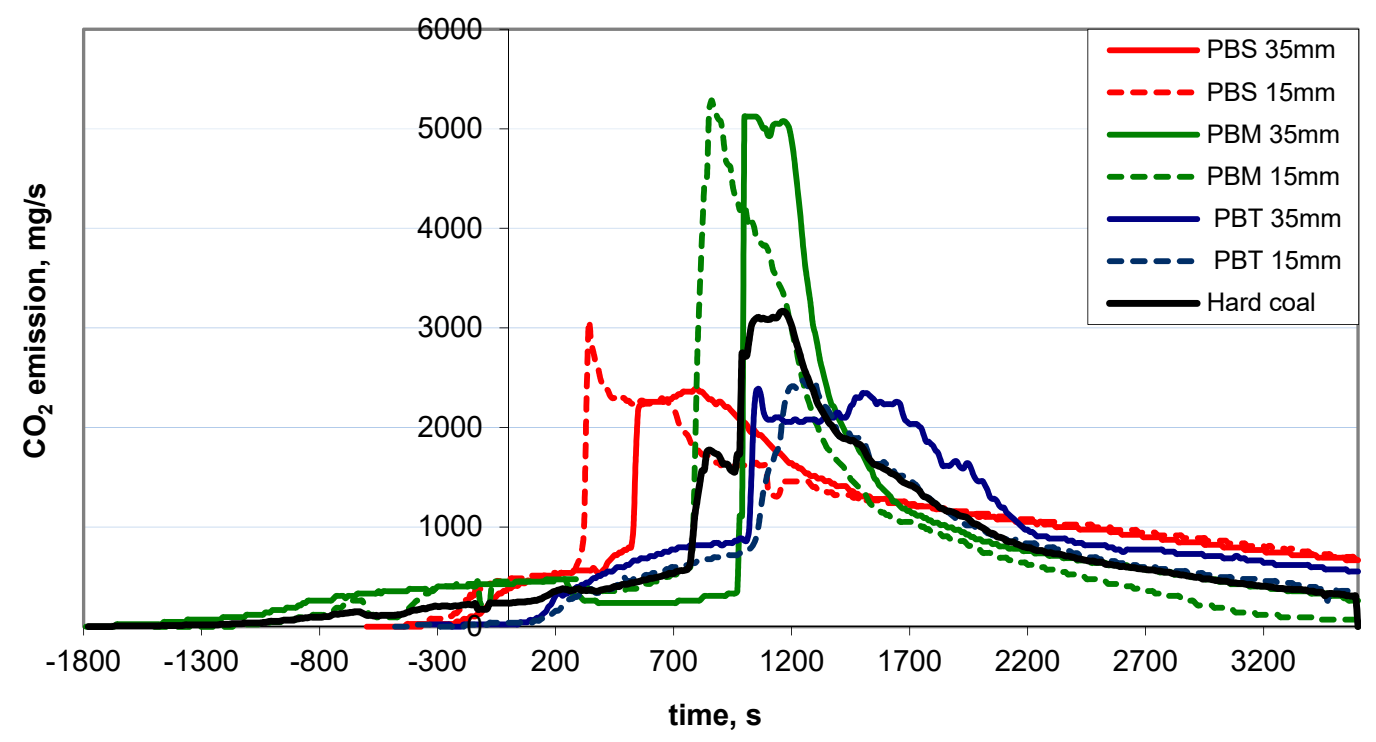

Figure 2. Variations of $\mathrm{CO}_{2}$ emissions during combustion of fuels.

Maximum values of $\mathrm{CO}_{2}$ emission were observed while burning the PBM fuel with both particle sizes. It contains meat and bone meal, and animal derived waste, as proved by the research of [34], burn faster than other fuels e.g., lignite. This can explain different behavior of PBM while combustion, as compared to other sludge fuels.

Analyzing Figure 2, it can be noted that for sewage sludge fuels, the fuels with lower particle sizes were ignited faster. The shortest ignition time is achieved for the PBS with particle size $15 \mathrm{~mm}$. Since the ignition time of a fuel depends mainly on the moisture content and the time of thermal decomposition of the organic matter, it can be concluded that the cause for a faster ignition of PBS is the lower moisture content than in other sludge fuels.

Figure 3 presents $\mathrm{CO}$ emissions achieved while combustion of the sewage sludge fuels.

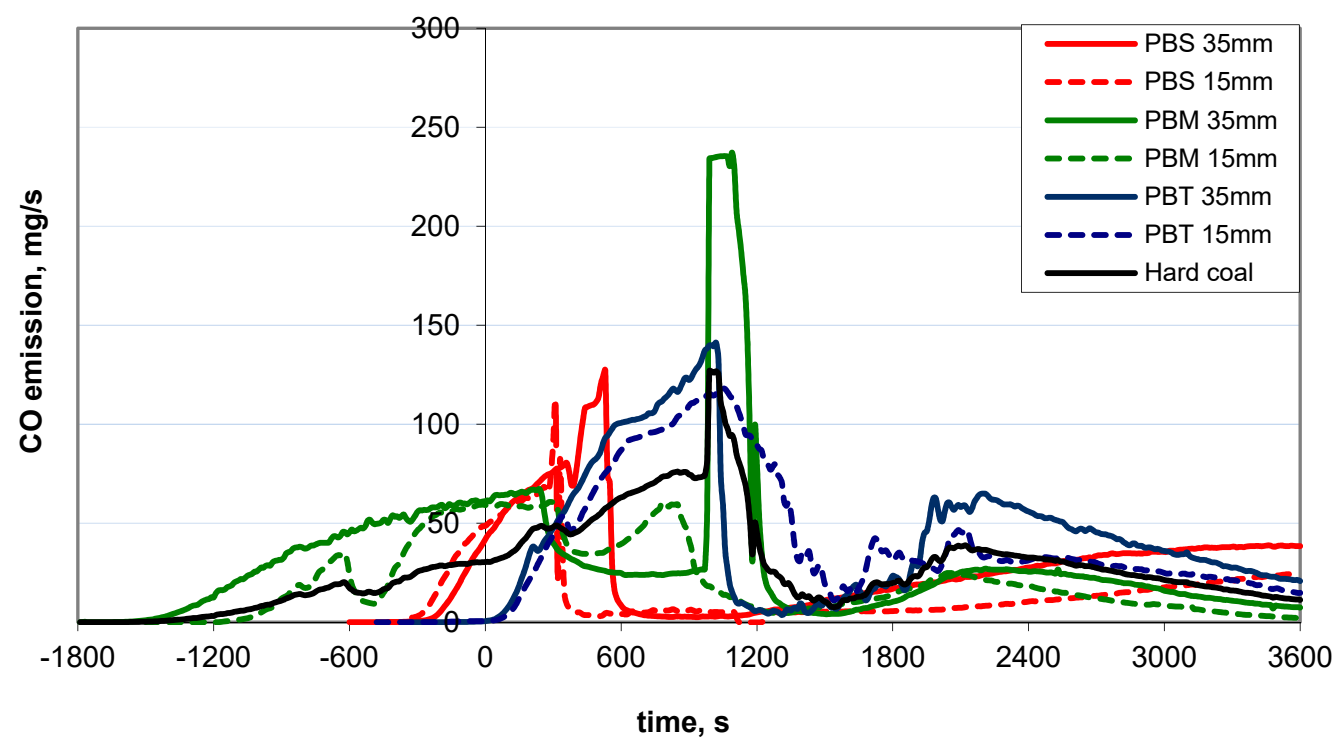

Figure 3. Variations of $\mathrm{CO}$ emissions during combustion of fuels.

Since the CO emission was observed to rise at point 0 , primary air was supplied. As a result, after a momentary increase, the $\mathrm{CO}$ emission would drop to 0 . The lower $\mathrm{CO}$ emissions were the result of a higher efficiency of the combustion process (and de facto reduced losses from incomplete combustion). Between 500 and 1500 s, after reaching the maximum values for individual fuels, $\mathrm{CO}$ 
emissions to values dropped close to 0 . After that, the $\mathrm{CO}$ emission values increased, not exceeding $60 \mathrm{mg} / \mathrm{s}$. According to Kozioł [39], such emission drops and increments are typical for burning fuels in grate furnaces. Naturally, adding some oxidizer to intensify the combustion process resulted in afterburning $\mathrm{CO}$ to $\mathrm{CO}_{2}$, as demonstrated by higher $\mathrm{CO}_{2}$ emissions (Figure 2). The delays observed in peaks (i.e., a large peak appearing after more than ten seconds following addition of the air) may result from the system inertia, reaction delay times, and the delay of the emission analyzer measurement path.

The combustion intensity was due to introducing air into the combustion chamber which in turn led to combustion of the flammable compounds of the fuel. For example, PBS fuel with $15 \mathrm{~mm}$ (Figure 3) produced high $\mathrm{CO}$ emissions beginning at -600 s time which continued until approximately $300 \mathrm{~s}$ after the air was fed at point " 0 ", only to drop suddenly (almost to $0 \mathrm{mg} / \mathrm{s}$ ) within roughly $300 \mathrm{~s}$. It means adding the air intensified the fuel combustion process, a fact attested to by the rapid increase of $\mathrm{CO}_{2}$ emission, i.e., the combustion product. Following this phase, $\mathrm{CO}_{2}$ emissions stabilized (starting at about 600 s to 800 s) owing to the complete combustion. CO oxidation occurs most likely in the $\mathrm{CO}+$ $\mathrm{OH}=\mathrm{CO}_{2}+\mathrm{H}^{\cdot}$ reaction, and thus it is the amount of hydroxyl radicals $\mathrm{OH}^{-}$in the emissions that most likely determines the chances of overreacting. At the same time, the $\mathrm{OH}$ concentration drops rapidly in sync with the temperature drop while the $\mathrm{CO}$ concentration remains higher than an equivalent one by an order of magnitude.

The so-called $\mathrm{CO}$ freeze effect may be explained by the higher emission levels of the substance in the latter phase of the combustion process. On the other hand, however, the $\mathrm{CO}_{2}$ emission reduction results primarily from the fuel being entirely used up (reduced combustion intensity) and, on the other hand, from a higher degree of incomplete combustion, even though its share in this case is rather marginal. One must also keep in mind the primary reasons for the $\mathrm{CO}$ emissions is the insufficient time the fuel substance remains inside the grate or its excessive cooling. The above described phenomenon may also be observed with other types of fuel and the time delay difference is attributable to the oxidant penetrating fuel particles, or the ratio of volatile matter to fix carbon in a given particle volume.

While measuring the $\mathrm{NO}_{2}$ concentration, in neither of the tests performed was it found in the flue gas. It may be due to the stabilization of temperature in the combustion chamber during the tests at the temperature level $900{ }^{\circ} \mathrm{C}$. $\mathrm{NO}_{2}$ is formed mainly as a result of reactions in temperatures lower than $750{ }^{\circ} \mathrm{C}$ [40]. The NO emission changes during combustion are shown in Figure 4. For all sludge fuels, very rapid increase of $\mathrm{NO}$ emission was observed in the time interval between 350 and $1500 \mathrm{~s}$.

For particle size $15 \mathrm{~mm}$, this value at $530 \mathrm{~s}$ was almost $9 \mathrm{mg} / \mathrm{s}$, and for $35 \mathrm{~mm}$, in the interval (790-830 s) - $7.8 \mathrm{mg} / \mathrm{s}$.

A probable cause of higher $\mathrm{NO}$ values, achieved while combustion of sludge fuels than for coal is the higher content of elementary nitrogen in the sludge fuels, which-by the subject literature including Boardman \& Smooth [41], Habi et al. [42] and Williams et al. [43]-is referred to as the fuel mechanism, one of three major causes for $\mathrm{NO}_{\mathrm{x}}$ formation.

In relation to $\mathrm{SO}_{2}$ momentary emissions (Figure 5), it can be noted that the highest values were noted while combustion of the PBS fuel (grain size $35 \mathrm{~mm}$ ), reaching $10 \mathrm{mg} / \mathrm{s}$ at $510 \mathrm{~s}$, and for the PBM fuel (grain size $35 \mathrm{~mm}$ ), for which the maximum was almost $9.90 \mathrm{mg} / \mathrm{s}$ at the $1020-1050 \mathrm{~s}$ interval. All curves, up to $1200 \mathrm{~s}$, are characterized by rapid fluctuations. The exception is the emission of the PBT fuel (grain size $35 \mathrm{~mm}$ ), for which the stabilization of $\mathrm{SO}_{2}$ emission changes occurs only at $2200 \mathrm{~s}$.

The results of measurements carried out on an industrial system of the stoker-fired boiler type ORS-16, in which hard coal was co-combusted with sewage sludge (mass content in the mixture being burnt $10 \%-30 \%$ ) presented in publication [44] prove that during combustion an increase of $\mathrm{NO}_{\mathrm{x}}$ emission by $10 \%-60 \%$, and $\mathrm{SO}_{2}$ by $10 \%-40 \%$ (compared to combustion of pure coal) was observed, depending on the amount of sludge added to coal. Increased emission of those compounds was accompanied by an increased share of sewage sludge in the mixture being burnt. 


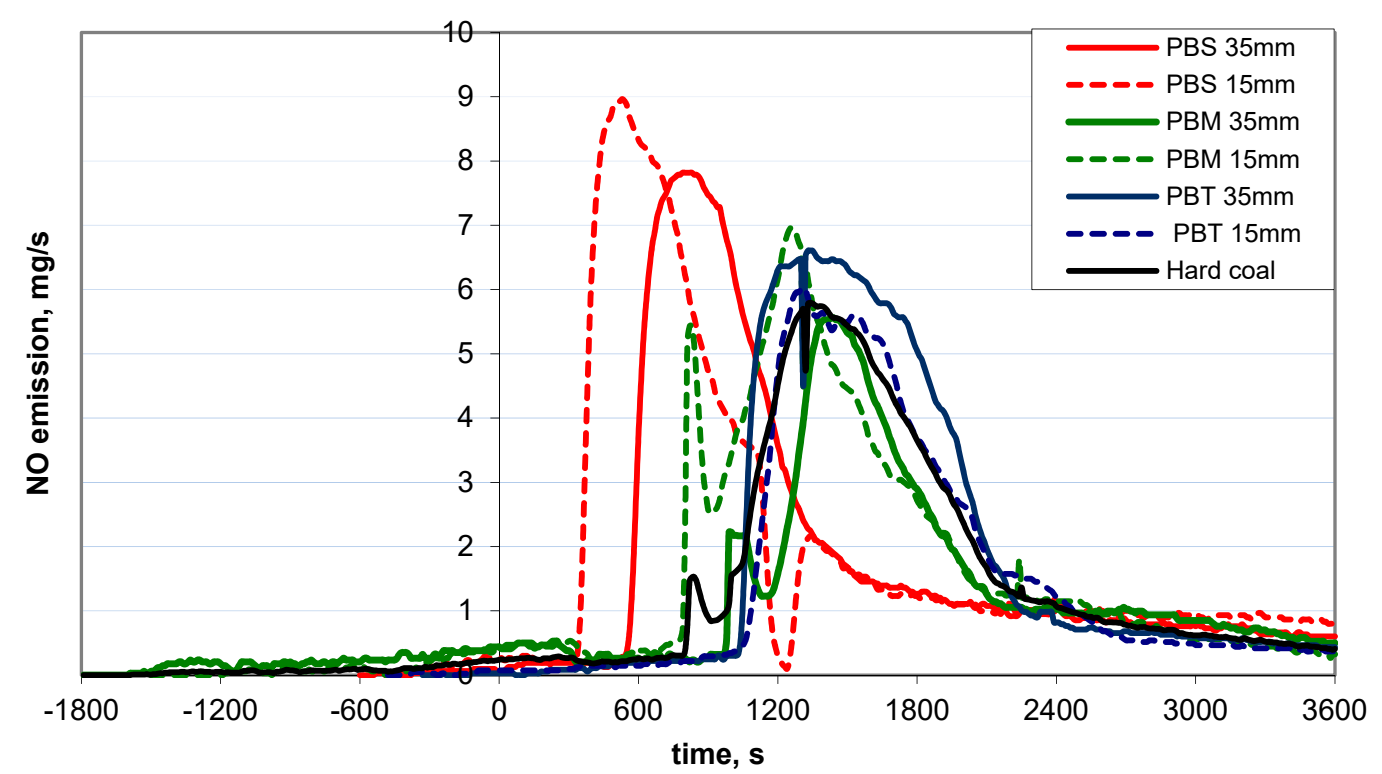

Figure 4. Variations of NO emissions during combustion of fuels.

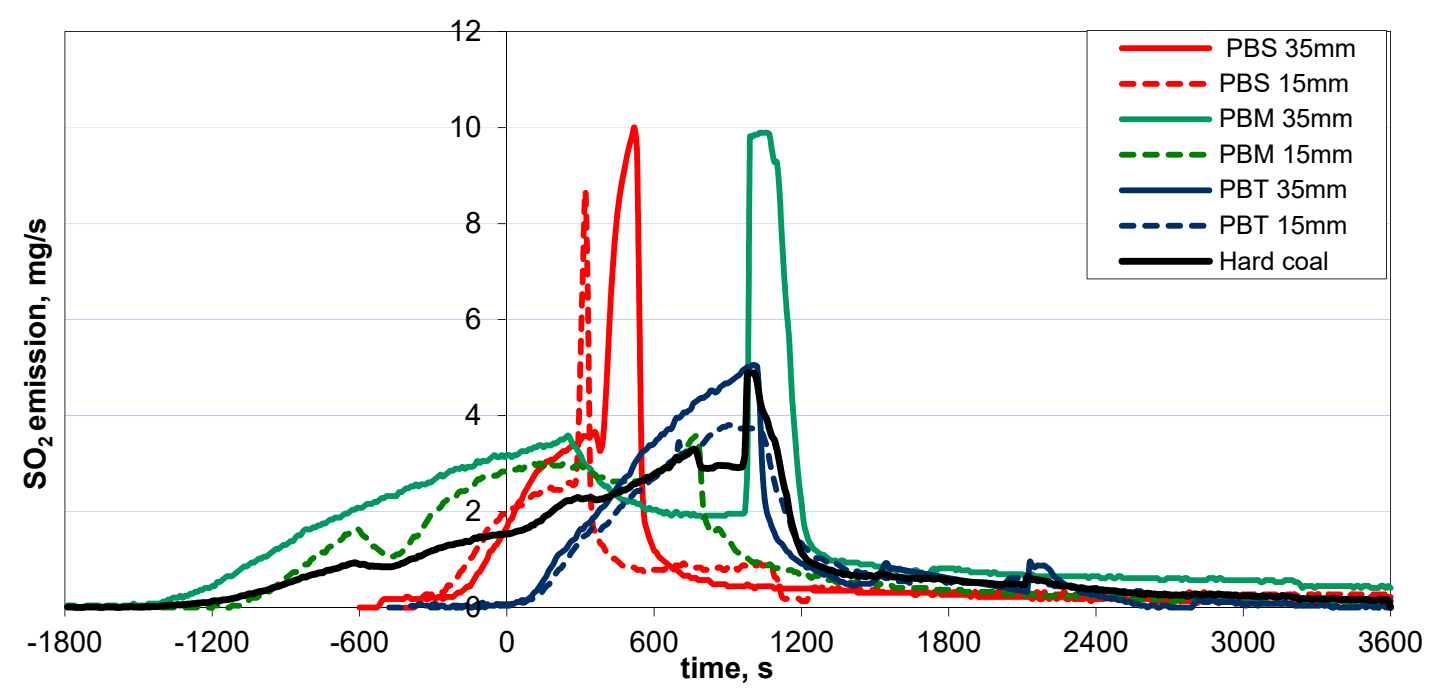

Figure 5. Variations of $\mathrm{SO}_{2}$ emissions during combustion of fuels.

Similar relationship is also described by Werther \& Ogada [3] for fluidized bed boilers, based, among others, on the tests performed by van Doorn et al. [45] as well as research carried out by Vamvuka et al. [46] in which the co-combustion of the sewage sludge was tested with hard coal, lignite, and other biomass materials. In all cases, as the mass content of sludge in the burnt mixture increased, also the $\mathrm{NO}_{\mathrm{x}}$ emission was increasing.

However, Morgan \& van de Kamp [47] based on their own research, concluded that for mass content of sludge above $50 \%$, the $\mathrm{NO}_{\mathrm{x}}$ emission reached its maximum, and after that, reduced with the increased share of sludge in the mixture being burnt.

As the practice shows, co-combustion of dried sludge with coal (with $1 \%$ share) does not increase the $\mathrm{NO}_{\mathrm{x}}$ concentrations, and the $\mathrm{SO}_{2}$ concentrations noted are even lower by $12 \%$ [44].

\subsection{Analysis of Ash and Slag and from Combustion of Sewage Sludge Fuels}

Chemical analyses of ashes from sewage sludge fuels compared to hard coal and biomass ashes are presented in Table 3. 
Table 3. Chemical composition of ashes.

\begin{tabular}{cccccc}
\hline Parameter ${ }^{*}$ \% & PBS & PBM & PBT & $\begin{array}{c}\text { Biomass } \\
\text { [48] }\end{array}$ & $\begin{array}{c}\text { Hard Coal } \\
\text { [49] }\end{array}$ \\
\hline $\mathrm{SiO}_{2}$ & $29.20 \pm 1.46$ & $17.88 \pm 0.89$ & $21.78 \pm 1.09$ & $0.12-15.12$ & $50-57$ \\
$\mathrm{Al}_{2} \mathrm{O}_{3}$ & $17.07 \pm 0.85$ & $4.04 \pm 0.20$ & $4.92 \pm 0.25$ & $0.04-68.18$ & $25-30$ \\
$\mathrm{Fe}_{2} \mathrm{O}_{3}$ & $8.41 \pm 42$ & $7.08 \pm 0.35$ & $11.80 \pm 0.59$ & $0.13-8.40$ & $3.5-8.0$ \\
$\mathrm{CaO}$ & $25.84 \pm 1.29$ & $40.35+2.02$ & $38.33 \pm 1.92$ & $4.39-83.46$ & $2-4$ \\
$\mathrm{MgO}$ & $0.01 \pm 0.00$ & $0.95 \pm 0.05$ & $1.15 \pm 0.06$ & $1.10-15.12$ & $1.5-3.0$ \\
$\mathrm{P}_{2} \mathrm{O}_{5}$ & $4.10+0.21$ & $21.06 \pm 1.05$ & $10.24 \pm 0.51$ & $0.45-18.24$ & n.d. \\
$\mathrm{SO}_{3}$ & $12.10 \pm 0.61$ & $0.50 \pm 0.27$ & $7.37 \pm 0.37$ & $0.36-45.89$ & $0.5-1.2$ \\
$\mathrm{Mn}_{3} \mathrm{O}_{4}$ & $0.14 \pm 0.01$ & $0.16 \pm 0.01$ & $0.25 \pm 0.52$ & n.d. & n.d. \\
$\mathrm{TiO}_{2}$ & $0.80+0.04$ & $0.36 \pm 0.02$ & $0.52 \pm 0.03$ & $0.05-28.00$ & $0-1$ \\
$\mathrm{SrO}_{\mathrm{Na}} \mathrm{O}$ & $0.10 \pm 0.01$ & $0.11 \pm 0.01$ & $0.15 \pm 0.01$ & n.d. & n.d. \\
$\mathrm{K}_{2} \mathrm{O}$ & $0.70 \pm 0.04$ & $1.11 \pm 0.06$ & $0.36 \pm 0.02$ & $0.14-29.82$ & $0.2-2.0$ \\
& $1.94 \pm 0.10$ & $1.25 \pm 0.06$ & $1.03 \pm 0.05$ & $2.19-37.70$ & $2.5-3.0$ \\
\hline
\end{tabular}

In biomass ash, there is usually a higher content of such components as $\mathrm{CaO}, \mathrm{MgO}, \mathrm{Na}_{2} \mathrm{O}, \mathrm{K}_{2} \mathrm{O}$, $\mathrm{P}_{2} \mathrm{O}_{5}$ and, at the same time, a lower content of $\mathrm{SiO}_{2}, \mathrm{Al}_{2} \mathrm{O}_{3}, \mathrm{TiO}_{2}$ in comparison to the ash from coal combustion. Vassilew et al. [50] ranged the oxide composition of fly ash from biomass combustion according to the following rule: $\mathrm{SiO}_{2}>\mathrm{CaO}>\mathrm{K}_{2} \mathrm{O}>\mathrm{P}_{2} \mathrm{O}_{5}>\mathrm{Al}_{2} \mathrm{O}_{3}>\mathrm{MgO}>\mathrm{Fe}_{2} \mathrm{O}_{3}>\mathrm{SO}_{3}>\mathrm{Na}_{2} \mathrm{O}>$ $\mathrm{MnO}>\mathrm{TiO}_{2}$. In sludge fuels, due to the addition of quicklime serving as a binder, the content of $\mathrm{CaO}$ in ashes is high. Particular attention should be paid to the content of approx. $21 \%$ of $\mathrm{P}_{2} \mathrm{O}_{5}$ in ash from fuel produced from sewage sludge and meat and bone meal (PBM). According to Febrero et al. [51] and other authors [52,53] high content of $\mathrm{P}_{2} \mathrm{O}_{5}$ will have effect on melting phases. Pronobis [25] stated that when ash fraction consists of pentoxide, hemispherical temperature (HT) is $569^{\circ} \mathrm{C}$ which enhances of low-melting-point phases in the fly ash. Tests carried out by Li et at. [52] have shown that $\mathrm{SiO}_{2}$ and $\mathrm{Al}_{2} \mathrm{O}_{3}$ are all favorable to increase the ash fusion temperature but $\mathrm{Al}_{2} \mathrm{O}_{3}$ is more effective than $\mathrm{SiO}_{2}$ in reducing the slagging tendency. The $\mathrm{SiO}_{2}$ content in fuel ashes is higher than that of $\mathrm{Al}_{2} \mathrm{O}_{3}$.

Table 4 shows the selected ash deposition indexes calculated according to formulas 1-4 in comparison to the criteria reported in the literature $[25,53]$.

Table 4. Ash deposition indexes and associated criteria.

\begin{tabular}{|c|c|c|c|c|c|c|c|c|c|}
\hline \multirow{2}{*}{ Parameter } & \multirow{2}{*}{ PBS } & \multirow{2}{*}{ PBM } & \multirow{2}{*}{ PBT } & \multirow{2}{*}{$\begin{array}{c}\text { Coal } \\
{[24]}\end{array}$} & \multirow{2}{*}{$\begin{array}{c}\text { Biomass } \\
\text { [24] }\end{array}$} & \multicolumn{4}{|c|}{ Criteria $[25,53]$} \\
\hline & & & & & & Low & Medium & High & Extremely High \\
\hline$B / A,-$ & 0.781 & 2.277 & 1.935 & 0.556 & 0.950 & $\begin{array}{l}<0.5 \\
<0.4\end{array}$ & $0.5-0.7$ & $\begin{array}{l}0.7-1 \\
>0.7\end{array}$ & $>1.0$ \\
\hline $\mathrm{B} / \mathrm{A}_{+\mathrm{P}},-$ & 0.868 & 3.222 & 2.311 & 0.557 & 0.980 & & & & \\
\hline$R_{b}, \%$ & 36.460 & 52.740 & 52.670 & 35.71 & 48.00 & $35-55$ & & & \\
\hline$S_{R},-$ & 46.241 & 26.985 & 29.811 & 62.55 & 76.34 & $>72$ & $65-72$ & $\leq 65$ & \\
\hline$R_{s},-$ & 0.211 & 0.767 & 0.394 & 0.742 & 0.106 & $<0.6$ & $0.6-2.0$ & $2-2.6$ & $>2.6$ \\
\hline $\mathrm{F}_{\mathrm{u},-}$ & 2.063 & 5.375 & 2.689 & 1.975 & 30.891 & $<0.6$ & & $0.6-40$ & $>40$ \\
\hline $\mathrm{Fe}_{2} \mathrm{O}_{3} / \mathrm{CaO}$,- & 0.33 & 0.17 & 0.31 & 0.810 & 0.025 & & & $0.3-3.0 *$ & \\
\hline $\mathrm{SiO}_{2}, \%$ & 29.20 & 17.88 & 21.78 & 53.73 & 50 & $<20$ & $20-25$ & $>25$ & $>0.5$ \\
\hline $\mathrm{Cl}^{\mathrm{r}}, \%$ & 0.06 & 0.02 & 0.03 & 0.5 & 0.5 & $<0.2$ & $0.2-0.3$ & $0.3-0.5$ & $>0.5^{\mathrm{a}}$ \\
\hline
\end{tabular}

* eutectics enhancing slag formation. ${ }^{\text {a }}$ - limit values for substance leaching according to Annex 3 of the Regulation of the Minister of Economy and Labor on the criteria and procedures for referring waste deposition on neutral waste landfill.

Base-to-acid ratio $(B / A)$ ratio indicates the potential tendencies for slagging and fouling. The highest $B / A$ index of the tested ashes is the one for PBM fuel and PBT fuel ash, which classifies them as extremally high prone to slagging and fouling (according to the criteria specified by Pronobis [25]). PBS fuel shows high tendency to be subject to those phenomena. For the base-to-acid ratios, $\mathrm{B} / \mathrm{A}_{+\mathrm{P}}$ which including $\mathrm{P}_{2} \mathrm{O}_{5}$ and is more closely to approach for biomass application a similar trend is clearly visible. 
According to research conducted by García-Maraver et al. [48] B/A ratio values for wood and woody biomass may range from 2.16-64.46, and even as high as 192.62 and 339.69 for paulownia wood and black poplar chips, respectively. For meat and bone meal (MBM), on the other hand, $B / A$ ratio is 38.90, for sewage sludge it is 1.08 , and 1.50 according to [25].

Additionally, for PBM ash the fouling index $F_{U}$ revealed that it had a strong tendency to fouling.

Slag viscosity index $S_{R}$ corresponds to high viscosity and therefore to low slagging inclination [25]. Values obtained for sewage fuel ashes demonstrate a high predisposition to slagging inclination similar to RDF fuel and agriculture biomass [48].

Ash from sludge fuels contains small amounts of chlorine, within $0.02 \%-0.06 \%$, which may indicate a low susceptibility to chloride corrosion of certain metal elements in combustion installation.

The residues after combustion process were analyzed for the presence of combustible matter in the ash and slag. The results are shown in Table 5. In the slag and ash after combustion process of sludge fuels less than $5 \%$ of combustible matter content was determined (condition specified by [54] for slags and ashes from co-combustion installations).

Table 5. Combustible matter content in slag and ash from sewage sludge fuels.

\begin{tabular}{ccc}
\hline \multicolumn{2}{c}{ Fuel Type } & Combustible Matter Content, $\%$ \\
\hline \multirow{2}{*}{ PBS } & $35 \mathrm{~mm}$ & 2.61 \\
& $15 \mathrm{~mm}$ & 1.60 \\
PBM & $35 \mathrm{~mm}$ & 2.80 \\
& $15 \mathrm{~mm}$ & 1.30 \\
\multirow{2}{*}{ PBT } & $35 \mathrm{~mm}$ & 1.43 \\
& $15 \mathrm{~mm}$ & 1.49 \\
\hline
\end{tabular}

Unburnt carbon can also be found in the ashes. For example, grate boilers often produce fly ash with $50 \%$ or more of unburnt carbon. As Demirbas [55] claims, the fly ash from biomass-fired grate boilers contains also high levels of unburnt carbon. The presence of this carbon indicates inefficient fuel use and can reduce ash stabilization (chemical hardening) and significantly increases ash volume.

The problem of storage of the residue after burning the sewage sludge fuels was also analyzed. One of the criteria determining the possibility to refer the waste to landfill, other than for hazardous waste, are the acceptable values of leaching the pollutants, as defined by [56], which acknowledges the correct choice of the combustion process parameters and its proper performance.

Therefore, the residue after combustion sewage sludge fuels was tested for leaching hazardous compounds. The results of analyses were compared with water extracts from biomass ashes and the criteria for approving waste for deposition on a neutral waste landfill, according to the regulation are listed in Table 6.

The data in Table 5 prove that the leaching of pollutants, in the extracts from sludge fuels residues after their combustion was, in each case, lower or equal (for mercury) the level determined by the regulation, so the ash and slag can be deposited on neutral waste landfill.

It is also possible that the ashes from sewage sludge fuels could be used in different ways. Ashes from combustion of conventional solid fuels have been used in production of building materials for many years and are used predominantly by the cement industry for cement and concrete production [57-61]. Their popularity in the construction engineering results, first and foremost, from its high fineness (close to cement), chemical and phase composition (close to mineral loam resources) and reactivity. The existing standard [62] defines the criteria of application of ashes as an additive to concrete and determines the maximum content of the fly ash from co-combustion materials to be $30 \%$. 
Table 6. Analysis of water extracts from the residues after combustion of sewage sludge fuels and biomass.

\begin{tabular}{ccccccc}
\hline Parameter & Unit & PBS & PBM & PBT & Biomass [56] & Limit Value $^{\mathbf{a}}$ \\
\hline $\mathrm{pH}$ & - & 9.60 & 9.80 & 9.00 & $12.9-13.3$ & - \\
Phosphates & $\mathrm{mg} \mathrm{PO}_{4} / \mathrm{L}$ & $<0.03$ & $<0.03$ & $<0.03$ & n.d. & - \\
Chlorides & $\mathrm{mg} \mathrm{Cl} / \mathrm{L}$ & 699.5 & 216 & 585 & n.d. & 800 \\
Sulfides & $\mathrm{mg} \mathrm{SO}_{4} / \mathrm{L}$ & 960 & 553 & 994 & n.d. & 1000 \\
$\mathrm{As}$ & $\mathrm{mg} / \mathrm{L}$ & 0.10 & 0.10 & 0.10 & $<0.022-0.024$ & 0.5 \\
$\mathrm{Cr}$ & & 0.43 & 0.28 & 0.32 & $0.065-2.85$ & 0.5 \\
$\mathrm{Zn}$ & & 0.10 & 0.10 & 0.10 & $<0.0315$ & 4.0 \\
$\mathrm{Cd}$ & & 0.01 & 0.01 & 0.01 & $<0.0007$ & 0.04 \\
$\mathrm{Cu}$ & & 0.10 & 0.10 & 0.10 & 0.0565 & 2.0 \\
$\mathrm{~Pb}$ & & 0.10 & 0.10 & 0.10 & $<0.00065-0.007$ & 0.5 \\
$\mathrm{Hg}$ & & 0.01 & 0.01 & 0.01 & n.d. & 0.01 \\
$\mathrm{Se}$ & & 0.30 & 0.30 & 0.30 & $0.007-0.135$ & 0.1 \\
$\mathrm{Fe}$ & & 0.01 & 0.14 & 0.47 & $<0.012$ & - \\
$\mathrm{Mn}$ & & 0.10 & 0.10 & 0.10 & $0.0055-0.0325$ & - \\
$\mathrm{Ba}$ & & 0.33 & 10.0 & 14.0 & n.d. & 20 \\
$\mathrm{~B}$ & & 0.30 & 0.30 & 0.30 & n.d. & - \\
\hline
\end{tabular}

a_-limit values for substance leaching according to Annex 3 of the Regulation of the Minister of Economy and Labor on the criteria and procedures for referring waste deposition on neutral waste landfill; n.d.-no data

As has already been mentioned, the chemical composition of biomass ashes includes mostly oxides, such as: $\mathrm{SiO}_{2}, \mathrm{CaO}, \mathrm{K}_{2} \mathrm{O}$. High phosphorus content (phosphate ions) can cause significant inhibition of hydration and postponement of the commencement and end of the cement curing time as well as a decline in its early strengths [60].

A prerequisite for use of ashes from new fuels in civil engineering, underground mines and other industries is fulfilment of legal requirements, including preparation of the relevant standards for new applications.

\section{Conclusions}

Despite the existence of many methods for the disposal of municipal sewage sludge, the problem of its management still exists. The use of sludge as a component of a biofuel with a fixed composition and properties allows the energetic use of sludge with lower calorific values and adjusting the quality of fuels to the requirements of a specific combustion installation.

While combustion of the sewage sludge transformed into pelletized biofuel, typical problems of co-combustion of dried sludge with coal can be avoided. Grain size composition of the sludge fuels is close to that of pea coal and adjusted to the grate firing process.

To sum up, it can be concluded that the tests performed showed some difference of the process of burning sewage sludge fuels as compared to hard coal. Momentary emission of $\mathrm{CO}_{2}, \mathrm{NO}$, and $\mathrm{SO}_{2}$ while combustion of fuels with the same composition, differing as to the grain size is similar. A noticeable difference between both particle sizes was the reduced ignition time and reduced emission of $\mathrm{CO}$ for fuels with smaller particles $(15 \mathrm{~mm})$.

Unfortunately, as in the case of co-combustion of dried sludge, the problem of $\mathrm{NO}_{x}$ emission still remains. However, while burning sludge fuels with coal, reducing the emission of nitrogen compounds can be expected, and the $\mathrm{NO}_{\mathrm{x}}$ emission (due to the fuel origin of nitrogen in the process discussed) will limit the share of sewage sludge fuels in the mixture being burnt.

The tendency for ash slagging and fouling is also observed, especially for PBM and PBT ashes which consist of MBM and sawdust which is typical for biomass combustion. Relatively high slagging and fouling indices of sludge limits its use in combustion.

It can be concluded that the test performed proved the potential of using sewage sludge fuels in co-combustion processes with coal in grate furnaces. 
Funding: This research was funded by the POLISH MINISTRY OF SCIENCE AND HIGHER EDUCATION, project No. R1401601.

Conflicts of Interest: The authors declare no conflict of interest.

\section{References}

1. Council Directive 86/278/EEC of 12 June 1986 on the Protection of the Environment, and in Particular of the Soil, when Sewage Sludge is Used in Agriculture; European Union: Brussels, Belgium, 2018.

2. Council Directive 99/31/EC of April 1999 on the Landfill of Waste; European Union: Brussels, Belgium, 2018.

3. Werther, J.; Ogada, T. Sewage sludge combustion. Prog. Energy Combust. Sci. 1999, 25, 55-116. [CrossRef]

4. Stasta, P.; Boráň, J.; Bébar, L.; Stehlik, P.; Oral, J. Thermal processing of sewage sludge. Appl. Therm. Eng. 2006, 26, 1420-1426. [CrossRef]

5. Sahu, S.; Chakraborty, N.; Sarkar, P. Coal-biomass co-combustion: An overview. Renew. Sustain. Energy Rev. 2014, 39, 575-586. [CrossRef]

6. Wzorek, M.; Troniewski, L. Application of sewage sludge as a component of alternative fuel. In Environmental Engineering; Dudzińska, M., Pawłowski, L., Eds.; Taylor \& Francis Group: New York, NY, USA, 2007; pp. 311-316.

7. Lin, Y.; Liao, Y.; Yu, Z.; Fang, S.; Ma, X. The investigation of co-combustion of sewage sludge and oil shale using thermogravimetric analysis. Thermochim. Acta 2017, 653, 71-78. [CrossRef]

8. Chen, J.; Liu, J.; He, Y.; Huang, L.; Sun, S.; Sun, J.; Chang, K.; Kuo, J.; Huang, S.; Ning, X. Investigation of co-combustion characteristics of sewage sludge and coffee grounds mixtures using thermogravimetric analysis coupled to artificial neural networks modeling. Bioresour. Technol. 2017, 225, 234-245. [CrossRef] [PubMed]

9. Xiao, H.; Ma, X.-Q.; Lai, Z. Isoconversional kinetic analysis of co-combustion of sewage sludge with straw and coal. Appl. Energy 2009, 86, 1741-1745. [CrossRef]

10. Yilmaz, E.; Wzorek, M.; Akçay, S. Co-pelletization of sewage sludge and agricultural wastes. J. Environ. Manag. 2018, 216, 169-175. [CrossRef]

11. Chen, G.-B.; Chatelier, S.; Lin, H.-T.; Wu, F.-H.; Lin, T.-H. A Study of Sewage Sludge Co-Combustion with Australian Black Coal and Shiitake Substrate. Energies 2018, 11, 3436. [CrossRef]

12. Rong, H.; Wang, T.; Zhou, M.; Wang, H.; Hou, H.; Xue, Y. Combustion Characteristics and Slagging during Co-Combustion of Rice Husk and Sewage Sludge Blends. Energies 2017, 10, 438. [CrossRef]

13. Huang, L.; Liu, J.; He, Y.; Sun, S.; Chen, J.; Sun, J.; Chang, K.; Kuo, J.; Ning, X. Thermodynamics and kinetics parameters of co-combustion between sewage sludge and water hyacinth in $\mathrm{CO}_{2} / \mathrm{O}_{2}$ atmosphere as biomass to solid biofuel. Bioresour. Technol. 2016, 218, 631-642. [CrossRef]

14. Akdağ, A.S.; Atak, O.; Atimtay, A.T.; Sanin, F.D. Co-combustion of sewage sludge from different treatment processes and a lignite coal in a laboratory scale combustor. Energy 2018, 158, 417-426. [CrossRef]

15. Kijo-Kleczkowska, A.; Środa, K.; Kosowska-Golachowska, M.; Musiał, T.; Wolski, K. Experimental research of sewage sludge with coal and biomass co-combustion, in pellet form. Waste Manag. 2016, 53, 165-181. [CrossRef] [PubMed]

16. Junga, R.; Kaszubska, M.; Wzorek, M. Technical and environmental performance of $10 \mathrm{~kW}$ understocker boiler during combustion of biomass and conventional fuels. E3S Web Conf. 2017, 19, 1009. [CrossRef]

17. Fleck, E.; Scholz, S. Co-combustion of sewage sludge in grate-based combustion plants. In Waste Management; Thome-Kozminski, K.J., Pelloni, L., Eds.; TK Verlag Karl-Kozminsky: Neuruppin, Gremany, 2011; pp. 779-798.

18. Nadziakiewicz, J.; Kozioł, M. Co-combustion of sludge with coal as a possible methods of its utilization in Poland. Appl. Energy 2003, 75, 239-248. [CrossRef]

19. Hroncová, E.; Ladomerský, J.; Musil, J. Problematic issues of air protection during thermal processes related to the energetic uses of sewage sludge and other waste. Case study: Co-combustion in peaking power plant. Waste Manag. 2018, 73, 574-580. [CrossRef] [PubMed]

20. Jang, H.-N.; Kim, J.-H.; Back, S.-K.; Sung, J.-H.; Yoo, H.-M.; Choi, H.S.; Seo, Y.-C. Combustion characteristics of waste sludge at air and oxy-fuel combustion conditions in a circulating fluidized bed reactor. Fuel 2016, 170, 92-99. [CrossRef]

21. Beckmann, M.; Pohl, M.; Bernhardt, D.; Gebauer, K. Criteria for solid recovered fuels as a substitute for fossil fuels-A review. Waste Manag Res. 2012, 30, 354-369. [CrossRef] 
22. Yina, C.; Li, S. Advancing grate-firing for greater environmental impacts and efficiency for decentralized biomass/wastes combustion. Energy Procedia 2017, 120, 373-379. [CrossRef]

23. Werle, S. Multivariate analysis of possibility of co-combustion of sewage sludge in coal fired power boilers. Arch. Waste Manag. Environ. Prot. 2011, 13, 21-38.

24. Houshfar, E.; Løvås, T. Skreiberg, Øyvind Experimental Investigation on NOx Reduction by Primary Measures in Biomass Combustion: Straw, Peat, Sewage Sludge, Forest Residues and Wood Pellets. Energies 2012, 5, 270-290. [CrossRef]

25. Pronobis, M. The influence of biomass co-combustion on boiler fouling and efficiency. Fuel 2006, 85, 474-480. [CrossRef]

26. Masiá, A.T.; Buhre, B.; Gupta, R.; Wall, T. Characterising ash of biomass and waste. Fuel Process. Technol. 2007, 88, 1071-1081. [CrossRef]

27. Baxter, L.L. Ash deposition during biomass and coal combustion: A mechanistic approach. Biomass- Bioenergy 1993, 4, 85-102. [CrossRef]

28. Theis, M.; Skrifvars, B.-J.; Hupa, M.; Tran, H. Fouling tendency of ash resulting from burning mixtures of biofuels. Part 1: Deposition rates. Fuel 2006, 85, 1125-1130. [CrossRef]

29. Jeong, T.-Y.; Sh, L.; Kim, J.-H.; Lee, B.-H.; Jeon, C.-H. Experimental Investigation of Ash Deposit Behavior during Co-Combustion of Bituminous Coal with Wood Pellets and Empty Fruit Bunches. Energies 2019, 12, 2087. [CrossRef]

30. Lee, J.M.; Kim, D.-W.; Kim, J.-S.; Na, J.-G.; Lee, S.-H. Co-combustion of refuse derived fuel with Korean anthracite in a commercial circulating fluidized bed boiler. Energy 2010, 35, 2814-2818. [CrossRef]

31. Dunnu, G.; Maier, J.; Scheffknecht, G. Ash fusibility and compositional data of solid recovered fuels. Fuel 2010, 89, 1534-1540. [CrossRef]

32. Kupka, T.; Mancini, M.; Irmer, M.; Weber, R. Investigation of ash deposit formation during co-firing of coal with sewage sludge, saw-dust and refuse derived fuel. Fuel 2008, 87, 2824-2837. [CrossRef]

33. Kanchanapiya, P.; Sakano, T.; Kanaoka, C.; Mikuni, T.; Ninomiya, Y.; Zhang, L.; Masui, M.; Masami, F. Characteristics of slag, fly ash and deposited particles during melting of dewatered sewage sludge in a pilot plant. J. Environ. Manag. 2006, 79, 163-172. [CrossRef]

34. Karcz, H.; Kozakiewicz, A.; Kantorek, M.; Dziugan, P.; Wierzbicki, K. Czy spalanie odpadów komunalnych w kotłach rusztowych jest właściwe. Instal 2011, 10, 24-30.

35. Wzorek, M. Characterization of the properties of alternative fuels contain sewage sludge. Fuel Process Technol. 2012, 104, 80-89. [CrossRef]

36. Wzorek, M. Physical and chemical properties of fuel containing animal waste. In Waste Management and the Environment IV; Zamorano, M., Ed.; WIT Transactions on Ecology and the Environment: Southampton, UK, 2008; Volume 109, pp. 69-77.

37. Wzorek, M.; Głowacki, T. A device for mixing, especially sewage sludge. Utility model PL W.121829, 31 July 2014.

38. Wzorek, M.; Kozioł, M.; Scierski, W. Emission characteristics of granulated fuel produced from sewage sludge and coal slime. J. Air Waste Manag. Assoc. 2010, 60, 1487-1493. [CrossRef] [PubMed]

39. Kozioł, M. Ecological and technical aspects of co-combustion of coal with substantial fraction of sludge in the grate-type boilers. Arch. Comb. 2010, 30, 409-426.

40. Wilk, K. Podstawy Niskoemisyjnego Spalania. Wydawnictwo Gnome PAN: Katowice, Poland, 2000; pp. 100-120.

41. Boardman, R.D.; Smoot, L.D. Pollutant formation and control. In Fundamentals of Coal Combustion for Clean and Efficient Use; Boardman, R.D., Smoot, L.D., Eds.; Elsevier Science Ltd.: Ansterdam, The Netherlands, 1993; pp. 433-506.

42. Habib, M.; Elshafei, M.; Dajani, M. Influence of combustion parameters on NOx production in an industrial boiler. Comput. Fluids 2008, 37, 12-23. [CrossRef]

43. Williams, A.; Pourkashanian, M.; Jones, J.M.; Rowlands, L. A review of $\mathrm{NO}_{\mathrm{x}}$ formation and reduction mechanisms in combustion systems with particular reference to coal. J. Energy Inst. 1997, 70, 102-113.

44. Wandrasz, J.W.; Kozioł, M.; Landrat, M.; Ścierski, W.; Wandrasz, A.J. Możliwości współspalania osadów z oczyszczalni ścieków z węglem w kotłach rusztowych. Gospod. Paliwami Energia 2000, 8, 10-15. 
45. van Doorn, J.; Bruyn, P.; Kos, B.; Hanse, J. Combined combustion of biomass, municipal sewage sludge and coal in a atmospheric fluidised bed installation. In Proceedings of the 9th European Biomass Conference for Energy and the Environment; Pergamon: Oxford, UK, 1996; pp. 199-210.

46. Vamvuka, D.; Alexandrakis, S.; Galetakis, M. Combustion Performance of Sludge from a Wastewater Treatment Plant in Fluidized Bed. Factorial Modeling and Optimization of Emissions. Front. Energy Res. 2019, 7. [CrossRef]

47. Morgan, D.J.; van de Kamp, W.L. The co-firing of biomass and municipal sewage sludge with pulverised coals in utility boilers. In Proceedings of the Second International Conference Combustion and Emissions Control, London, UK, 4-5 December 1995; pp. 159-168.

48. Garcia-Maraver, A.; Mata-Sanchez, J.; Carpio, M.; Perez, J.A. Critical review of predictive coefficients for biomass ash deposition tendency. J. Energy Inst. 2017, 90, 214-228. [CrossRef]

49. Jarosiński, A. Mineral and chemical composition of fly ashes deriving from co-combustion of biomass with coal and its application. J. Pol. Min. Eng. Soc. 2013, 14, 141-148.

50. Vassilev, S.V.; Baxter, D.; Andersen, L.K.; Vassileva, C.G. An overview of the composition and application of biomass ash. Fuel 2013, 105, 19-39. [CrossRef]

51. Febrero, L.; Granada-Álvarez, E.; Regueiro, A.; Míguez, J.L. Influence of Combustion Parameters on Fouling Composition after Wood Pellet Burning in a Lab-Scale Low-Power Boiler. Energies 2015, 8, 9794-9816. [CrossRef]

52. Li, Q.; Zhang, Y.; Meng, A.; Li, L.; Li, G. Study on ash fusion temperature using original and simulated biomass ashes. Fuel Process. Technol. 2013, 107, 107-112. [CrossRef]

53. Viana, H.; Vega-Nieva, D.; Torres, L.O.; Lousada, J.; Aranha, J. Fuel characterization and biomass combustion properties of selected native woody shrub species from central Portugal and NW Spain. Fuel 2012, 102, 737-745. [CrossRef]

54. Ordinance of the Polish Minister of Economy and Labour on the requirements to the process of thermal conversion of waste for slag and ash from co-combustion of waste. J. Laws 2002, 37, 339.

55. Demirbas, A. Potential applications of renewable energy sources, biomass combustion problems in boiler power systems and combustion related environmental issues. Prog. Energy Combust. Sci. 2005, 31, 171-192. [CrossRef]

56. Ordinance of the Polish Minister of Economy and Labour on the criteria and procedures for the acceptance of waste for land filling. J. Laws 2005, 186, 1553.

57. Maresca, A.; Hyks, J.; Astrup, T. Recirculation of biomass ashes onto forest soils: Ash composition, mineralogy and leaching properties. Waste Manag. 2017, 70, 127-138. [CrossRef] [PubMed]

58. Kurama, H.; Kaya, M. Usage of coal combustion bottom ash in concrete mixture. Constr. Build. Mater. 2008, 22, 1922-1928. [CrossRef]

59. Król, A. The role of the silica fly ash in sustainable waste management. 1st International Conference on the Sustainable Energy and Environment Development (SEED). E3S Web Conf. 2016, 10, 00049. [CrossRef]

60. Kuterasińska, J.; Król, A. Mechanical properties of alkali-acivated binders based on copper slag. Arch. Civil Eng. Environ. 2015, 8, 61-67.

61. Król, A. Binding chromium ions during hydratation of mineral binders. Przem. Chem. 2007, 86, 971-973.

62. PN-EN 450-1: 2012 Fly Ash for Concrete-Part 1: Definitions, Specifications and Compliance Criteria; Polish Committee for Standardization: Warsaw, Poland, 2012.

(C) 2020 by the author. Licensee MDPI, Basel, Switzerland. This article is an open access article distributed under the terms and conditions of the Creative Commons Attribution (CC BY) license (http://creativecommons.org/licenses/by/4.0/). 